\title{
The Effectual Approach in Born Global Firms: Current State of Research
}

\author{
Elena Pawęta
}

\section{A B S T R A C T}

Objective: The aim of this paper is to systematise the existing research the intersection of international entrepreneurship and effectuation theories and propose the future research directions in this area.

Research Design \& Methods: The research was carried out with the help of the literature review, where the articles reviewed were mostly published within the last decade (2005-2015) and come from scientific journals specialising in entrepreneurship research.

Findings: The theoretical contribution of the study is the summary and critical analysis of the existing research on the application of effectuation logic in the international entrepreneurship field and propositions for further research.

Implications \& Recommendations: The results of the study are exploratory and there is a need for future empirical research at the intersection of international entrepreneurship and effectuation research.

Contribution \& Value Added: The research highlighted the division of the existing literature into two streams - papers which claim that international entrepreneurs use causation logic and the ones that argue on the application of effectuation theory. The paper suggests the areas of further research within those literature streams.

\begin{tabular}{|c|c|}
\hline $\begin{array}{l}\text { Article type: } \\
\text { Keywords: }\end{array}$ & $\begin{array}{l}\text { original literature review } \\
\text { born globals; international entrepreneurship; internationalisation; ef- } \\
\text { fectuation; effectuation logic }\end{array}$ \\
\hline JEL codes: & $\mathrm{F} 23$ \\
\hline Received: 15 January 2016 & Accepted: 15 May 2016 \\
\hline
\end{tabular}

\section{Suggested citation:}

Pawęta, E. (2016). The Effectual Approach in Born Global Firms: Current State of Research. Entrepreneurial Business and Economics Review, 4(2), 105-115, DOI: http://dx.doi.org/10.15678/EBER.2016.040209 


\section{INTRODUCTION}

Company internationalisation became a subject of interest for researchers at the end of the 20th century. Those studies focused on the attitudes and behaviour of firms in the process of going international (Li \& Cavusgil, 1995). Despite dissimilarities in definitions, researchers mainly agreed that the internationalisation process has several consecutive stages. Stage internationalisation theories (Johanson \& Wiedersheim-Paul, 1975; Johanson \& Vahlne, 1977) were mainly based on large multinational corporations which developed from large, mature domestic companies (Oviatt \& McDougall, 1994). Later international entrepreneurship researchers (McDougall \& Oviatt, 2000; Zahra \& George, 2002) examined the possibilities to conduct business activities globally with limited resources. Since then, rapidly internationalising firms or "born globals" (Rennie, 1993; Knight \& Cavusgil, 1996) became a very popular research subject. Such firms are defined as business organisations that, from inception, seek to derive significant competitive advantage from the use of resources and the sale of outputs in multiple countries (Oviatt \& McDougall, 1994, p. 49).

There are many research papers trying to explain the key determinants of the international expansion of born globals. Most of the researchers show the combination of external factors, internal factors and factors related to the entrepreneur (Zahra \& George, 2002). External factors are mainly associated with the market characteristics, as sectoral or regional export culture, international trade incentives or demand characteristics. Internal, organisational reasons of going international are niche products, global strategy and resource availability (Pawęta \& Zbierowski, 2015). Entrepreneur-related reasons, however, are found to be fundamental in the internationalisation of a company.

The recent stream of research on effectuation logic applied in international entrepreneurship deepens the significance of entrepreneurial approach in born global companies. Several studies connecting international orientation of companies with the effectual way of thinking have appeared within the last decade (Bhowmick, 2008; Mainela \& Puhakka, 2008; Schweizer, Vahlne, \& Johansson, 2010; Sarasvathy, Kumar, York, \& Bhagavatula, 2014; Galkina \& Chetty, 2015). The theory of effectuation, entrepreneurial way of thinking and making decisions in situations of uncertainty, first introduced in 2001 by Saras Sarasvathy, includes considering available means, keeping in mind what is affordable to lose, then seeking strategic partnerships and exploiting contingencies to control the unpredictable future (Sarasvathy, 2001). According to Sarasvathy, effectual thinking is the prevalent logic among expert entrepreneurs in uncertain environments. Rapid internationalisation of born global companies is a highly uncertain environment for a novice entrepreneur. Therefore, effectual thinking is considered to be one of the key entrepreneur-related constructs determining the early internationalisation of firms (Pawęta, 2015).

This paper aims to systematise the existing research on the effectual approach in born global firms through the critical literature review and to present implications for further research within this area. The research is based on the systematic literature review (Pawęta, 2015) conducted on the sample of 94 articles from 41 scientific journals, which showed that the effectual approach is one of the main constructs determining the early internationalisation of born global companies. This paper discusses the literature stream which connects effectuation with international entrepreneurship and presents insights for 
future research (Mainela \& Puhakka, 2008; Schweizer, Vahlne \& Johanson, 2010; Sarasvathy et al., 2014). The paper demonstrates that there is a potential for future investigation of the effectual approach in born global firms.

The first part of the paper describes the theoretical background of the effectuation concept in entrepreneurship studies, the next part presents the methodology used in the study. The third section elaborates on the findings of the literature review. The last part presents final remarks, research limitations and suggestions for further research.

\section{LITERATURE REVIEW}

The theory of effectuation, entrepreneurial way of thinking and making decisions in situations of uncertainty was introduced in 2001 by Sarasvathy. She introduced two distinct types of logic used in decision-making processes - causation and effectuation. Causation refers to typical managerial rational behaviour, where decisions are based on searching the ways to reach a distinct goal. Causation usually starts with a given goal, then focusing on expected returns and competitive analysis and finally assembling means to achieve the given goal. Effectuation includes a set of decision-making behaviours which are employed in the situations of uncertainty, when future is unpredictable, goals are not clearly known and there is no independent environment that serves as the ultimate selection mechanism. Effectual thinking includes considering available means, keeping in mind what is affordable to lose, then seeking for strategic partnerships and exploiting contingencies to control the unpredictable future (Sarasvathy, 2001). According to Sarasvathy, effectual thinking is the prevailing logic among expert entrepreneurs in uncertain environments. Rapid internationalisation of born global companies is a highly uncertain environment for a novice entrepreneur.

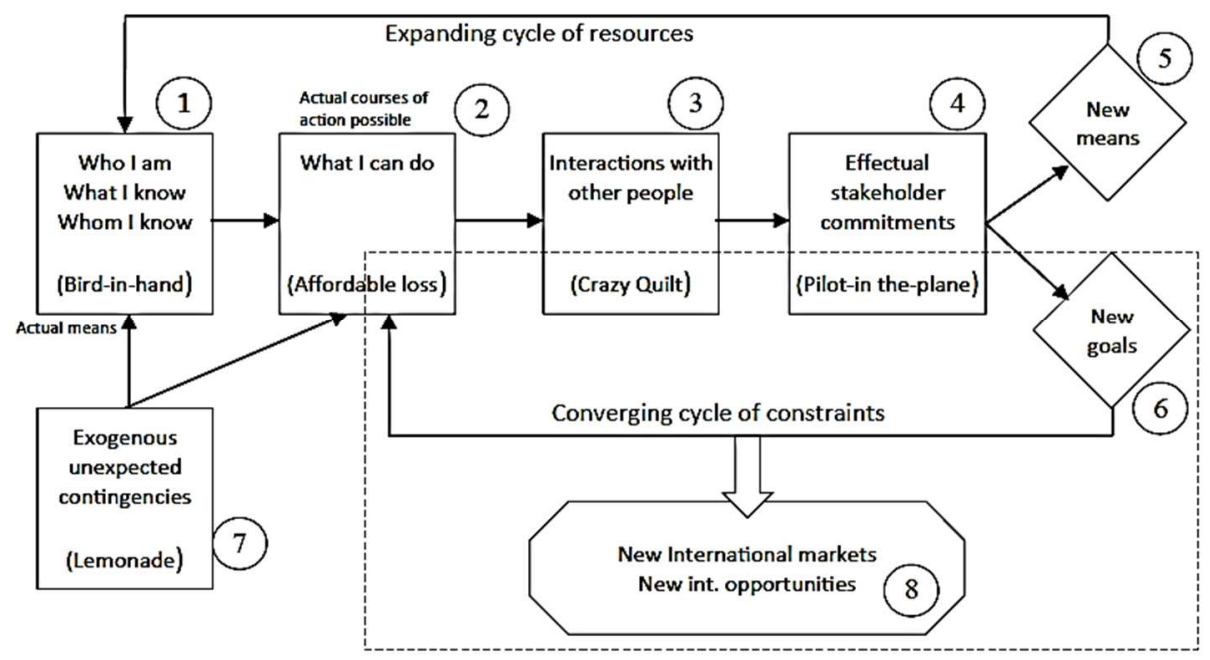

Figure 1. Effectuation theory

Source: Sarasvathy, 2008. 
The main effectuation principles introduced by Sarasvathy (2008) are called bird-inhand, affordable loss, crazy quilt, lemonade and pilot-in-the-plane (Figure 1).

\section{Bird-in-hand}

Before starting any activity, an entrepreneur analyses the means he or she has associated with identity (who I am), knowledge (what I know) and networks (whom I know). This analysis helps the entrepreneur to focus on what he can do rather than what he should or wants to do. Such a means-based approach helps to generate potential opportunities. According to Sarasvathy et al. (2014), by relying on means rather than on ends, effectuation encourages entrepreneurs to be open to new possibilities and to be finely attuned to their own capabilities.

\section{Affordable loss}

It is impossible to predict the future returns while acting in an uncertain environment. Therefore, expert entrepreneurs focus on what they can afford to lose, but not on what they can gain (Dew et al, 2009; Sarasvathy, 2008). This part of effectuation strategy reduces time engaged in strategic planning, as affordable loss can be calculated relatively quickly, and eliminates the need to predict the future returns.

\section{Crazy quilt}

According to the effectual approach, partnerships are the central method to expand resources (Sarasvathy et al., 2014). The effectual approach suggests that entrepreneurs do not search for specific stakeholders based on their strategic goals and preselected targets, but they engage in conversations with a variety of people they already know and by that they find stakeholders with whom they end up making commitments to a new venture. Effectual entrepreneurs tend to create possibilities for stakeholders who risk their assets because they see an opportunity in cocreating the venture with the entrepreneur (Kurczewska, 2012). Chandler, DeTienne, McKelvie and Mumford (2011) notes that entrepreneurs may build relationships, but only when both parties share the risk of the venture and benefit from the success of the venture, they constitute effectual partnership.

\section{Lemonade}

The effectual approach suggests that entrepreneurs "turn lemons to lemonade", which means that they treat surprises as opportunities and by that may control uncertain situations to some extent. The "lemonade" principle allows to benefit from embracing unexpected situations rather than following a goal-oriented process that requires stability and no deviations from the plan (Chandler et al., 2011). There is empirical evidence that embracing surprises strategy has a positive impact on the R\&D output in highly innovative research settings (Brettel, Mauer, Engelen, \& Kuepper, 2012).

\section{Pilot-in-the-plane}

The pilot-in-the-plane principle emphasises the role of human beings rather than trends in determining the shape of future events (Sarasvathy, 2008). In the uncertain environment effectual entrepreneurs do not seek to learn more about it by extensive market research or estimating upcoming trends, but they intervene in the event space, transform and reshape it themselves or with the help of other effectual actors (Sarasvathy et al., 
2013). Effectual entrepreneurs do not see events running on autopilot, but consider themselves one of the co-pilots of the ongoing events.

\section{METHODOLOGY}

The author's previous systematic literature review on the main entrepreneur-related factors which influence rapid internationalisation (Pawęta, 2015) set the theoretical framework and defined methodological choices for further in-depth research on effectuation logic as one of the main constructs in early internationalisation studies. In this paper 6 main constructs were revealed within the systematic review of 94 articles from 41 scientific journals. Those constructs are: innovation and technology, entrepreneurial/managerial knowledge, entrepreneurial orientation, effectuation logic, international networks and dynamic capabilities of an entrepreneur. The systematic literature review presented above became a basis for the further research on effectual approach in born global firms.

In order to describe the current state of knowledge within the application of the effectuation theory in international entrepreneurship, the literature review was carried out. The articles reviewed were mostly published within the last decade (2005-2015) and come from the international scientific journals specialising in entrepreneurship research, such as "Entrepreneurship: Theory and Practice", "Journal of International Entrepreneurship", "Management International Review". The articles were chosen with the use of the methodology applied for the previous research (Pawęta, 2015) using a three-stage procedure:

1. Using bibliographic database Web of Science which allows to access the most significant international scientific journals in the fields of social sciences, art and humanities. The following keywords in different combinations were used: "effectuation", "effectual logic", "born global”, "internationalisation", "entrepreneurial orientation".

2. Analysing references of the articles found, especially literature reviews and conceptual papers.

3. Screening the articles in order to check their relevance to the research and selecting the final sample.

The final sample includes scientific papers which can be divided into two main categories - conceptual papers or literature reviews and empirical research on the effectuation influence on rapid internationalisation of companies. The main observations which emerged within the literature review are presented and discussed in the following section.

\section{RESULTS AND DISCUSSION}

The review of the international entrepreneurship literature and its connection with effectuation logic was aimed at defining the current state of research at the intersection of those two fields of study. The literature reviewed starts with the first work of Sarasvathy (2001) on effectuation logic, includes further papers on effectuation in international entrepreneurship (Mainela \& Puhakka, 2008; Schweizer, Vahlne \& Johansson, 2010) and the latest insights on this topic (Sarasvathy et al., 2014; Galkina \& Chetty, 2015). The key findings and methodological aspects of the papers reviewed are presented in Table 1, which shows the key findings and methodological choices of the authors researching the effectual approach in born global companies. 
Table 1. The effectual approach in born global companies in the international literature

\begin{tabular}{|c|c|c|c|}
\hline $\begin{array}{c}\text { Author, } \\
\text { Year }\end{array}$ & Sample & $\begin{array}{l}\text { Research } \\
\text { method }\end{array}$ & Main results \\
\hline $\begin{array}{l}\text { Bhowmick, } \\
2008\end{array}$ & $\begin{array}{l}4 \text { case stud- } \\
\text { ies }\end{array}$ & Qualitative & $\begin{array}{l}\text { The internationalisation process is a combination of } \\
\text { enactment and effectuation. The enactment con- } \\
\text { cept is quite similar to effectuation, it means that } \\
\text { entrepreneurs, being a part of the situation they } \\
\text { face, act without the entire knowledge of the situ- } \\
\text { ation, though both the situation and the decisions } \\
\text { are often rationalised in retrospect. }\end{array}$ \\
\hline $\begin{array}{l}\text { Mainela } \\
\text { \& Pu- } \\
\text { hakka, } \\
2008\end{array}$ & $\begin{array}{l}1 \text { case study } \\
\text { of IJV }\end{array}$ & Qualitative & $\begin{array}{l}\text { International entrepreneurship is a complicated } \\
\text { process which requires a set of means which are - } \\
\text { effectuation logic, proactiveness and partnering } \\
\text { strategies. }\end{array}$ \\
\hline $\begin{array}{l}\text { Chandra, } \\
\text { Styles \& } \\
\text { Wilkinson, } \\
2009\end{array}$ & $\begin{array}{l}8 \text { case stud- } \\
\text { ies of SMEs } \\
\text { operating in } \\
\text { knowledge- } \\
\text { based in- } \\
\text { dustries }\end{array}$ & Qualitative & $\begin{array}{l}\text { Companies with no prior international experience } \\
\text { tend to use opportunities rather than apply system- } \\
\text { atic research. However, firms with international } \\
\text { knowledge apply information from their networks } \\
\text { and discover international opportunities using pre- } \\
\text { existing means (resources, skills, technologies). }\end{array}$ \\
\hline $\begin{array}{l}\text { Schweizer } \\
\text { et al., } \\
2010\end{array}$ & 1 case study & Qualitative & $\begin{array}{l}\text { The authors updated their conceptual model from } \\
1977 \text { and } 2009 \text { and included entrepreneurial as- } \\
\text { pects, like the effectuation principle. Their updated } \\
\text { model includes the "exploiting contingencies" vari- } \\
\text { able leading to progress in the internationalisation } \\
\text { process. The authors agree that effectuation logic } \\
\text { can strongly contribute to internationalisation of } \\
\text { firms. }\end{array}$ \\
\hline $\begin{array}{l}\text { Anders- } \\
\text { son, } 2011\end{array}$ & 2 case study & Qualitative & $\begin{array}{l}\text { Effectuation introduces a pro-active entrepreneur- } \\
\text { ial perspective that better describes the firm's de- } \\
\text { velopment than earlier theories used to analyse } \\
\text { born globals' iternationalisation. }\end{array}$ \\
\hline $\begin{array}{l}\text { Harms } \\
\text { \& Schiele, } \\
2012\end{array}$ & $\begin{array}{l}65 \text { rapidly } \\
\text { growing } \\
\text { SMEs }\end{array}$ & $\begin{array}{l}\text { Quantita- } \\
\text { tive }\end{array}$ & $\begin{array}{l}\text { Entrepreneurs tend to apply effectuation rather } \\
\text { than causation. The author stresses the importance } \\
\text { of the individual level of analysis in international } \\
\text { entrepreneurship research. }\end{array}$ \\
\hline $\begin{array}{l}\text { Sarasvathy } \\
\text { et al., } \\
2014\end{array}$ & 1 case study & Qualitative & $\begin{array}{l}\text { The effectual approach can resolve conflicts and } \\
\text { knowledge gaps in two reviews of IE. The authors } \\
\text { offer four possibilities for future research at the in- } \\
\text { tersection of IE and the effectuation research. }\end{array}$ \\
\hline $\begin{array}{l}\text { Galkina } \\
\text { \& Chetty, } \\
2015\end{array}$ & $\begin{array}{l}7 \text { case stud- } \\
\text { ies }\end{array}$ & Qualitative & $\begin{array}{l}\text { International entrepreneurs network with inter- } \\
\text { ested partners, instead of careful selection of inter- } \\
\text { national partners. }\end{array}$ \\
\hline
\end{tabular}

Source: Own study, based on (Pawęta, 2015).

Table 1 presents the articles which focus on the effectual orientation of the entrepreneur in born global firms. However, several researchers stress that born global entrepreneurs use a planned and analytical approach to business, which contradicts the effectual 
approach (Brewer, 2007, cited in Harms \& Schiele, 2012). For example, the research by Brouthers \& Nakos (2005) showed that exporters use a systematic international market selection to outperform others, which illustrates the causation-based approach. That was followed by Gruber's (2007) argumentation that an expert entrepreneur may need both causation and effectuation ways of thinking when developing a new venture. This duality can be observed in the literature on international entrepreneurship. On the one hand, authors state that international entrepreneurs use the networking approach to build strategic international partnerships (Harris, Wheeler, 2005), that in the initial years the growth of the enterprise occurs without a formal or planned marketing effort (Frishammar \& Andersson, 2009), which reflects the effectual logic of entrepreneurs. On the other hand, several papers state that there is evidence from the export literature showing a positive relationship between export planning and export performance (Brouthers \& Nakos, 2005; Lucas, Whitewell \& Hill, 2007). However, Harms and Schiele (2012) suggest that born global entrepreneurs do not have much time for strategic planning, conscientious research and analysis of global markets in the dynamic uncertain environment they operate in.

The studies presented in Table 1 suggest that effectual logic is prevailing among born global entrepreneurs. The first one to use the effectuation theory within the international entrepreneurship research was Bhowmick (2008). He describes the internationalisation process as a combination of enactment and effectuation. The enactment concept is quite similar to effectuation, it means that entrepreneurs, being a part of the situation they face, act without the entire knowledge of the situation, though both the situation and the decisions are often rationalised in retrospect (Bhowmick, 2008). Bhowmick proposes a model called the "enactment-effectuation dance", which illustrates that high levels of both enactment and effectuation can be a key to the international success. Mainela and Puhakka (2008) show that international entrepreneurship is a complicated process which requires a set of means which are - effectuation logic, proactiveness and partnering strategies. The connection between effectuation and entrepreneurial orientation was also suggested by Chandra et al. (2009) in the study which says that the aggressive way of exploiting contingencies during internationalisation is similar to effectuation logic proposed by Sarasvathy (2001).

In 2010 Schweizer, Vahlne and Johanson proposed an update for the famous U-model from 1977, where they suggested that networks are crucial for successful internationalisation. They stated that the business environment is a web of relationships, a network, and they suggested that the effectuation principle is consistent with their model. Therefore, the authors updated their conceptual model and included entrepreneurial aspects, among all the effectuation principle. They state that "such a view of rationality corresponds better with, often unintentional, internationalisation of a company as a result of managerial or entrepreneurial efforts - the view taken in this paper" (Schweizer, Vahlne, \& Johanson, 2010). Their updated model, presented in Figure 2, includes the "exploiting contingencies" variable leading to progress in the internationalisation process. The authors agree that effectuation logic can strongly contribute to the internationalisation of firms. 


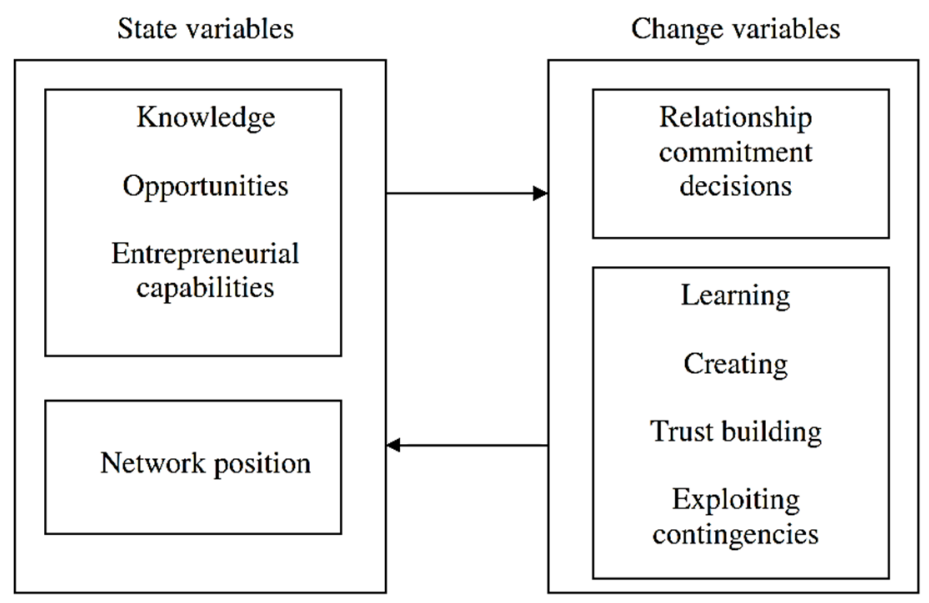

Figure 2. Internationalisation as an entrepreneurial process. Updated model of the 1977 Uppsala internationalisation model Source: Schweizer et al., 2010.

An approach integrating effectuation into the international entrepreneurship theory was introduced by Sarasvathy et al. (2014). The authors state that their new model (Schweizer et al., 2010) "strongly and explicitly emphasizes the role of effectuation in the internationalization process" (Sarasvathy et al., 2014, p.79) and suggest ways to expand the international entrepreneurship research by combining it with effectuation research. The three characteristics of cross-border business presented by Sarasvathy et al. (2014, p. 76) justify the application of the effectuation theory in born global research: (1) crossborder uncertainty, (2) limited resources and (3) network dynamics.

The effectuation theory has gained attention among the international entrepreneurship researchers because internationalisation is an entrepreneurial process of decisionmaking under uncertainty (Harms \& Schiele, 2012; Sarasvathy et al., 2014). Furthermore, the importance of the individual level of analysis in international entrepreneurship research is stressed. Andersson (2011) proposes to focus on decision making in the internationalisation context. Using a case study method, the author analyses born global entrepreneurial decisions using the effectuation theory. According to Andersson, effectuation introduces "a pro-active entrepreneurial perspective that better describes the firm's development than earlier theories used to analyse born globals' internationalisation" (2011, p. 637). The effectuation theory and earlier research on born globals use the resourcebased view and the network approach, therefore, according to Andersson, effectuation should be included in future research on born globals. He also recommends further research on individual entrepreneur's behaviour in the context of born global internationalisation.

The results of the research show that there is a need to focus on individual-level analysis of international entrepreneurship (Andersson, 2011). That justifies the application of the effectuation theory in born global firms research. High uncertainty on the global markets and limited initial resources push born global entrepreneurs towards the effectual way of making decisions. 


\section{CONCLUSIONS}

The aim of this paper was to systematise the existing research on the effectual approach in born global firms. The research was based on the systematic literature review (Pawęta, 2015) conducted on the sample of 94 articles on the international entrepreneurship topic, which showed that the effectual approach is one of the main constructs determining the early internationalisation of born global companies.

This article presents work which connects effectuation with international entrepreneurship and suggests insights for future research. The research presented suggests that the effectuation theory can explain the entrepreneurial behaviour of born global entrepreneurs. It is stressed by Sarasvathy et al. (2014), whereas born global activity involves cross-border uncertainty, limited resources and network dynamics, which is coherent with the effectuation logic characteristics. There is evidence that causation logic is also applied by international entrepreneurs (Brouthers \& Nakos, 2005; Lucas, Whitewell \& Hill, 2007), however, there is an increasing trend in the research on internationalisation, which shows that effectual logic is prevailing among born global entrepreneurs.

There are certain research limitations which do not allow to conduct a broader analysis. Mainly, they are based on the limited amount of literature and research on this topic. As the effectuation analysis and its application in international entrepreneurship has been shaping during the last decade, there is still no defined conceptual framework and there is a lack of advanced empirical studies.

The paper shows that there is a potential for future investigation of the effectual approach in born global firms. The study summarises the existing research on the application of effectuation logic in the international entrepreneurship field. However, the results of the study are exploratory and there is a need for future empirical research at the intersection of international entrepreneurship and effectuation research. The results of the literature review are a starting point for further detailed analysis on effectual logic applied by born global entrepreneurs and its impact on internationalisation speed and scope.

\section{REFERENCES}

Andersson, S. (2011). International entrepreneurship, born globals and the theory of effectuation. Journal of Small Business and Enterprise Development, 18(3), 627-643.

Bhowmick, S. (2008). Internationalisation of entrepreneurial firms: an enactment-effectuation dance. Proceedings of the 5th AGSE International Entrepreneurship Research Exchange, Melbourne, Feb 2008, 785-974.

Brettel, M., Mauer, R., Engelen, A., \& Kuepper, D. (2012). Corporate effectuation: Entrepreneurial action and its impact on R\&D project performance. Journal of Business Venturing, 27(2), 167184.

Brewer, P.A. (2007). Operationalizing Psychic Distance: A Revised Approach. Journal of International Marketing, 15(1), 44-66.

Brouthers, L. E., \& Nakos, G. (2005). The Role of Systematic International Market Selection on Small Firms' Export Performance. Journal of Small Business Management, 43(4), 363-381.

Chandler, G.N., DeTienne, D.R., McKelvie, A., \& Mumford, T.V. (2011). Causation and effectuation processes: A validation study. Journal of Business Venturing, 26(3), 375-390. 
Chandra, Y., Styles, C., \& Wilkinson, I. (2009). The recognition of first time international entrepreneurial opportunities. International Marketing Review, 26(1), 30-61.

Czinkota, M.R. (1982). Export Development Strategies US Promotion Policies, Praeger Special Studies: New York.

Dew, N., Sarasvathy, S., Read, S., \& Wiltbank, R. (2009). Affordable loss: Behavioral economic aspects of the plunge decision. Strategic Entrepreneurship Journal, 3(2), 105-126.

Frishammar, J., \& Andersson, S. (2009). The overestimated role of strategic orientations for international performance in smaller firms. Journal of International Entrepreneurship, 7(1), 57-77.

Galkina, T., \& Chetty, S. (2015). Effectuation and networking of internationalizing SMEs. Management International Review, 55(5), 647-676.

Gruber, M. (2007). Uncovering the value of planning in a new venture creation: A process and contingency perspective. Journal of Business Venturing, 22(6), 782-807.

Harms, R., \& Schiele, H. (2012). Antecedents and consequences of effectuation and causation in the international new venture creation process. Journal of International Entrepreneurship, 10(2), 95-116.

Harris, S., \& Wheeler, C. (2005). Entrepreneurs' relationships for internationalization: functions, origins and strategies. International Business Review, 14(2), 187-207.

Johanson, J., \& Wiedersheim-Paul, F. (1975). The Internationalization of the Firm - Four Swedish Cases. Journal of Management Studies, 12(3), 305-322.

Johanson, J., \& Vahlne, J.E. (1977). The Internationalisation Process of the Firm. Journal of International Business Studies, 8(1), 23-32.

Li, T., \& Cavusgil, S.T. (1995). A Classification and Assessment of Research Streams in International Marketing. International Business Review, 4(3), 251-277.

Knight, G.A., \& Cavusgil, S.T. (1996). The Born Global Firm: A Challenge to Traditional Internationalization Theory, in: S.T. Cavusgil, T.Madsen (eds.), Advances in International Marketing, 8, 11-26.

Kurczewska, A. (2012). W jaki sposób myślą przedsiębiorcy? - czyli „Jeśli mogę kontrolować przyszłość, nie muszę jej przewidywać". E-mentor, 5(47).

Lukas, B.A., Whitwell, G.J., \& Hill, P. (2007). Export planning orientation and its antecedents: Evidence from exporting IT products. Journal of Business Research, 60(12), 1282-1289.

Mainela, T., \& Puhakka, V. (2008). Organising new business in a turbulent context: Opportunity discovery and effectuation for IJV development in transition markets. Journal of International Entrepreneurship, 7(2), 111-134.

McDougall, P.P., \& Oviatt, B.M. (2000). International Entrepreneurship: The Intersection of Two Research Paths. Academy of Management Journal, 43(5), 902-906.

Oviatt, B.M., \& McDougall, P.P. (1994). Toward a theory of international new ventures. Journal of International Business Studies, 25(1), 44-64.

Pawęta, E. (2015). Entrepreneur-Related Constructs Explaining the Emergence of Born Global Firms: A Systematic Literature Review. Entrepreneurial Business and Economics Review, 3(4), 11-36.

Pawęta, E., \& Zbierowski, P. (2015). Individual-level determinants of international orientation of a firm: A study based on Global Entrepreneurship Monitor data. Journal of Intercultural Management, 7(1), 43-58.

Rennie, M.W. (1993). Global Competitiveness: Born Global. The McKinsey Quarterly, 4.

Sarasvathy, S.D. (2001). Causation and effectuation: Toward a theoretical shift from economic inevitability to entrepreneurial contingency. Academy of Management Review, 26(2), 243-263.

Sarasvathy, S.D. (2008). Effectuation: Elements of entrepreneurial expertise. Cheltenham, U.K.: Edward Elgar.

Sarasvathy, S., Kumar, K., York, J.G., \& Bhagavatula, S. (2014). An effectual approach to international entrepreneurship: Overlaps, challenges, and provocative possibilities. Entrepreneurship, Theory and Practice, 38(11), 71-93.

Sarasvathy, S.D., Menon, A.R., \& Kuechle, G. (2013). Failing firms and successful entrepreneurs: Serial entrepreneurship as a temporal portfolio. Small Business Economics, 40(2), 417-434. 
Schweizer, R., Vahlne, J.E., \& Johanson, J. (2010). Internationalization as an entrepreneurial process. Journal of International Entrepreneurship, 8(4), 343-370.

Zahra, S.A., \& George, G. (2002). International Entrepreneurship, The Current Status of the field and Future Research Agenda. In: M.A. Hitt, R.D.Ireland, S.M.Camp, D.L.Sexton, Strategic entrepreneurship: Creating a New Mindset, Oxford: Blackwell Publishers.

\section{Author}

\section{Elena Pawęta}

Master in Human Resources Management (Saint Petersburg State University, Russia); Master in Business and Organisation (Technical University of Lodz, Poland); PhD student in the Faculty of Economics and Sociology at the University of Lodz, Poland. Her main research interests are entrepreneurship and business planning. She is particularly interested in the early internationalization of enterprises.

Correspondence to: Elena Pawęta, University of Lodz, Faculty of Economics and Sociology, UI. POW 3/5, 90-255, Łódź, Poland, e-mail: elena.paweta@gmail.com

\section{Copyright and License}

This article is published under the terms of the Creative Commons Attribution - NonCommercial - NoDerivs (CC BY-NC-ND 3.0) License http://creativecommons.org/licenses/by-nc-nd/3.0/ 